\title{
INTO THE ABYSS: INTERNATIONAL REGULATION OF SUBSEABED NUCLEAR WASTE DISPOSAL
}

\author{
ROBERT A. KAPLAN†
}

"No generation has a freehold on this earth. All we have is a life tenancywith a full repairing lease."

\section{INTRODUCTION}

-Margaret Thatcher ${ }^{1}$

The nuclear age has been marked by fantastic scientific advances without corresponding development in humankind's social, political, or legal capacity to deal with technological problems. ${ }^{2}$ The "solution" to threats such as nuclear war or power plant accidents has been sought through more and better technology. The nuclear nations have plunged into weapons manufacture and energy production, putting faith in technology to handle the most predictable consequence of such development: the production of vast quantities of high level nuclear waste (HLW). ${ }^{3}$ The result of this

† B.A. 1987, Carleton College; J.D. Candidate 1991, University of Pennsylvania.

I would like to thank Professor Jonathan I. Charney of Vanderbilt University School of Law for his invaluable research advice and helpful comments on earlier drafts. Of course, the author bears sole responsibility for the opinions expressed and for any remaining errors.

1 The Politics of Posterity, in Costing the Earth: A Survey of the Environment, ECONOMIST, Sept. 2, 1989, at Survey 3, Survey 3.

${ }^{2}$ See RESHAPING THE INTERNATIONAL ORDER 40 (A. Dolman ed. 1976) (prepared as a report to the Club of Rome with $\mathrm{J}$. Tinbergen serving as coordinator); TECHNOLOGY AND PoLITICs 4 (M. Kraft \& N. Vig eds. 1988); L. WINNER, AUTONOMOUS TEGHNOLOGY 3 (1977).

${ }^{3} \mathrm{HLW}$ generally includes spent reactor fuel and all other wastes that release higher specified levels of radioactivity, measured in curies. See International Atomic Energy Agency, Convention on the Prevention of Marine Pollution by Dumping of Wastes and Other Matter, INFCIRC/205/Add.1/Rev.1 (1978), reprinted in I8 INT'L LEGAL MATERIALS 826 (1979) [hereinafter 1978 IAEA Revised Definition]. For the purposes of Annex I to the London Dumping Convention, discussed infra notes 38-73 and accompanying text, the International Atomic Energy Commission (IAEA) has defined HLW as

any waste or other matter with an activity per unit gross mass (in tonnes) exceeding:

(a) $1 \mathrm{Ci} / \mathrm{t}$ for $\alpha$-emitters but limited to $10^{-1} \mathrm{Ci} / \mathrm{t}$ for ${ }^{226} \mathrm{Ra}$ and supported ${ }^{210} \mathrm{Po}$;

(b) $10^{2} \mathrm{Ci} / \mathrm{t}$ for $\beta /{ }^{*}$-emitters with half-lives of at least 0.5 years (excluding tritium) and $\beta /{ }^{*}$-emitters of unknown half-lives; and

(c) $10^{6} \mathrm{Ci} / \mathrm{t}$ for tritium and $\beta /{ }^{*}$-emitters with half-lives of less than 0.5 years. 
approach has been a kind of nuclear shell game. While awaiting some sort of technological solution, waste has been continually transferred from one medium or temporary storage facility to another, creating a shortage of interim capacity and hazardous conditions. ${ }^{4}$

Congress responded to the need for a permanent containment of HLW by passing the Nuclear Waste Policy Act of 1982 (NWPA). ${ }^{5}$ At the time, Congress considered several alternative methods of waste reduction and isolation. Congress favored mined continental geologic disposal and eschewed the alternatives, including subseabed disposal (SSD), which involves the emplacement of nuclear wastes in deep ocean sediment. ${ }^{6}$ Consequently, the Act's principal aim became the siting and construction of two terrestrial repositories by the end of the tweritieth century.

The above activity concentrations shall be averaged over a gross mass not exceeding 1000 tonnes.

Id. at 828.

${ }^{4}$ Most of the civilian HLW produced is "sitting in pools of filtered, cooled water next to the reactors that created them." Wald, Finding a Burial Place for Nuclear Wastes Grows More Difficult, N.Y. Times, Dec. 5, 1989, at C1, col. 4 [hereinafter Burial Place]. Nearly 20,000 metric tons of waste awaits disposal, and the total is expected to rise to 87,000 metric tons by the time existing nuclear plants go off-line. Utilities are expected to outstrip on-site capacity and may be forced to stop operating when capacity is reached. Congressional plans for additional temporary storage have been delayed for further study. See Lippman, Atom-Waste Issue Tossed Back to Hill, Wash. Post, Nov. 2, 1989, at A58, col. 1 .

Military wastes pose a more critical problem. Many high level wastes from the Manhattan project were diluted with water and chemicals and placed at the Washington State Hanford facility in steel tanks, which eventually leaked. Even newer double lined steel tanks built in the late 1970s and early 1980s have developed rust pits, "cast[ing] doubt on the integrity of the approximately 200 tanks at the Hanford and Savannah River" facilities. Alvarez \& Makhijani, Nuclear Waste: The \$100-billion Mess, Wash. Post, Sept. 4, 1988, at C3, col. 1. A pilot project designated to accept certain military wastes has been delayed for years due to engineering problems. Perhaps most troublesome is the potential for temporarily stored wastes to explode, as happened in 1957 in Kyshtym, Soviet Union. See Wald, Running Out of Space for Nuclear Waste, N.Y. Times, Oct. 22, 1989, at E7, col. 1.

${ }^{5}$ Pub. L. No. 97-425, 96 Stat. 2202 (1983) (codified as amended at 42 U.S.C. $\S \S 10,101-26$ (1988)).

6 Congress followed the Department of Energy's proposal in selecting deep geologic disposal. The seabed alternative was rejected because of potential international political problems, wather than technical reasons. See Energy Department Ordered to Re-examine Ocean Disposal of High-Level Radioactive Waste, Env't Rep. (BNA) No. 37, at 1996, 1997 (Jan. 8, 1988) [hereinafter Energy Department] (quoting Dick Nelson, director of the Office of Congressional and Public Affairs for Department of Energy's Office of Civilian Radicractive Waste Management). 
Implementation of the "solution," however, has been exceedingly difficult, from both a political and a technical standpoint. Siting of the facilities has been highly contentious, as several states with potentially suitable geology have mounted fierce opposition to hosting a permanent facility. After five years of not-in-my-back-yard $(\mathrm{NIMBY})^{7}$ intergovernmental conflict, Congress in 1987 instructed the United States Department of Energy (DOE) to evaluate the suitability of Yucca mountain in Nevada and to build the repository at that site unless an insurmountable problem arose. ${ }^{8}$

The DOE has concentrated on deep geologic isolation and the two billion dollar Yucca suitability investigation. Its narrow focus has nearly excluded consideration of any other waste disposal strategy, including SSD. A primary concern has been to avoid jeopardizing the fragile consensus achieved in selecting the Nevada site. $^{9}$ Most recently, however, DOE's single-minded strategy has

7 The NIMBY reaction to siting undesirable activities is a well documented phenomenon. See, e.g., Briffault, Our Localism: Part II-Localism and Legal Theory, 90 ColUM. L. REv. 346, 442-43 \& nn.411-12 (1990) (citing instances of NIMBY behavior); Glaberson, Coping in the Age of 'Nimby', N. Y. Times, June 19, 1988, at F1, col. 2 (same).

${ }^{8}$ See Nuclear Waste Policy Amendments Act of 1987, Pub. L. No. 100-202, 101 Stat. 1329-104 (1987) (codified at 42 U.S.C. \$ 10,172 (1988)).

Some have suggested that sparsely populated Nevada "lost" the siting war as much due to its relative political impotence as any significant geologic considerations. Former Sen. Chic Hecht (R., Nev.), the most outspoken critic of the Yucca siting, was a junior senator appointed to fill a vacated seat and lacked a technical background, having been a clothing merchant before becoming a senator. In a public speech, Senator Hecht mistakenly referred to a HLW facility as a "nuclear suppository." Reinhold, Nevada Senator's Hope is Revived, N.Y. Times, Oct. 30, 1988, at 30, col. 1.

${ }^{9}$ See Civilian Radioactive Waste Disposal: Hearings Before the Committee on Energy and Natural Resources, 100th Cong., 1st Sess. $247-49$ (1987) (statement of Charles D. Hollister) [hereinafter Waste Disposal Hearings] (noting that DOE viewed the subseabed disposal project as competition to the land repository program). Prior to enactment of the NWPA in 1982, DOE had been conducting considerable research on seabed emplacement since it was identified by the Carter administration as an alternative to geologic disposal. See Finn, Ocean Disposal of Radioactive Wastes: The Obligation of International Cooperation to Protect the Marine Environment, 21 VA. J. INT'L L. 621, 642 (1981). DOE abruptly terminated seabed research projects in 1986, ostensibly for budgetary reasons. See Baker, DOE Funding Cut Puts End to Subseabed Waste Disposal Research, NUCLEARFUEL, Dec. 29, 1986, at 7 (quoting a DOE researcher as saying "they [DOE] feel that the only way they're going to get a [geologic] repository is if they have no alternatives"). The projects had been conducted out of the Civilian Radioactive Waste Management Office, which also oversees the Yucca project. See Energy Department, supra note 6, at 1996-97. In an effort to preserve alternatives to deep geologic disposal, Senator Hecht attached a rider to the NWPA amendments of 1987 that directed DOE to set up an Office of Subseabed Disposal Research, establish a university-based seabed consortium, and submit progress reports to Congress. See id. at 1996. The consortium did not form for lack of funds. Despite 
proven to be misguided. Initial DOE testing has revealed significant problems with the Yucca site, raising doubts concerning its ultimate viability. The DOE's senior geologist recently recommended that the site be dropped from consideration because of the threat of volcanic activity near the mountain, itself a volcanic ash structure. ${ }^{10}$ Further, there are crucial determinations concerning potential contact with the biosphere which must be made. For instance, an accurate prediction of changes in the water table for at least the next 10,000 years is proving difficult if not impossible. ${ }^{11}$ The difficulties with this site thus call into question the potential for any form of permanent deep geologic disposal, and leave the United States unable to satisfy the NWPA's 1998 completion date for a permanent disposal option.

Given the uncertainty surrounding terrestrial disposal, there will surely be renewed interest in options the DOE has previously forsaken. None of these alternatives promises a realistic solution to the increasingly urgent problem of high-level waste disposal. At best, each represents a partial solution, serving as either a secondary remedy or temporary measure.

Some of the alternatives, such as waste emplacement in polar caps or ejection into extraterrestrial space, are riskier, costlier, and more technologically complex than land disposal, and are likely to be rejected again. ${ }^{12}$ Surface storage at either a central facility or near nuclear reactors as a final disposal option, while relatively cheap and simple, has been rejected on social, political, and environmental grounds. ${ }^{13}$ Reprocessing of nuclear wastes, widely

a DOE promise to reprogram funds from elsewhere for the new office, this was not done and DOE's budget requests have not included requests for work on subseabed disposal. See Marshall \& Hiruo, U.S. Disinterest in Subseabed Work Could Stymie International Research, NUCLEARFuEL, Nov. 14, 1988, at 5.

${ }^{10}$ See Burial Place, supra note 4, at C12, col. 4. The senior geologist, John Trapp, predicted that the site would have serious difficulty passing a Nuclear Regulatory Commission licensing hearing on the basis of volcanic activity alone. See id.

11 See id. at C12, col. 1-4. The water table below the proposed site inexplicably rises in one corner. It is also uncertain whether the site will remain a desert throughout the requisite time period. See id.

${ }^{12}$ See Walker, Science and Tecinnology of the Sources and Management of Radioactive Wastes, in TOO Hot To HANDLE 61-62 (C. Walker, L. Gould \& E. Woodhouse eds. 1983). A variant of surface storage, Monitored Retrievable Storage (MRS), calls for storage of nuclear waste at a central surface repository until a more permanent facility comes on line. MRS was considered by Congress in 1987 as an amendment to the NWPA. A blue ribbon commission created by Congress recently recommended that Congress cancel any plans for an MRS facility and continue the search for a final disposal option. See Lippman, stupra note 4, at A58, col. 1.

13 See D. DeEse, Nuclear Power and Radioactive Waste: A Sub-Seabed 
used in other nuclear nations, has been limited in this country to military wastes and would face tremendous political opposition if extended to civilian power generation. ${ }^{14}$

Thus, barring discovery of any breakthrough transmutation process ${ }^{15}$ in the next decade, the United States likely will resort to some form of sea-based disposal in the near future. ${ }^{16}$ The same result is even more likely for nuclear countries such as Japan and England, whose size and geology impose tight constraints in siting a permanent geologic facility. ${ }^{17}$ In many respects, SSD seems to present a highly satisfactory way of dealing with high-level waste: the vast depth of the water column tends to isolate the radionuclides from human activity; certain ocean plates are among the most stable geologic formations on earth; and, ocean sediments bond with radionuclides to immobilize them. ${ }^{18}$ In many respects, however, SSD has the potential to be humankind's most fateful decision. Similar to the nuclear power and weapon proliferation that gave rise to the waste disposal problem, SSD is unforgiving of errors. A miscalculation in planning, design, or execution could have catastrophic effects, not only for the present generation, but also for millennia. Careful decision-making now is imperative.

The international order of the ocean environment is presently in its formative stages. In recent years, there has been a shift away from the notion that the oceans are "the ultimate 'sink' through

DISPOSAL OPTION? 8 (1978).

${ }^{14}$ See Burial Place, supra note 4, at $\mathrm{Cl}$, col. 4. Reprocessing involves chemical treatment of spent fuel to remove its plutonium, an extremely dangerous radioactive element with a 24,000 year half-life, for use in fueling a reactor. Its atoms are then split, turning the plutonium into elements with half-lives of only a few hundred years, and resulting in a product which may be disposed of more safely and easily.

The process has had its most success and is used most commonly in France. See generally Waste Disposal Hearings, supra note 9, at 285-89 (statement of J. Lefevre, Commissariat a L'Energie Atomique). The United States has not reprocessed spent fuel because of its high cost and the danger that commerce in plutonium could lead to weapons proliferation. See Burial Place, supra note 4, at C1, col. 4.

${ }^{15}$ Transmutation would involve "converting the radioactive nuclei of the wastes to either nonradioactive nuclei or to nuclei with shorter half-lives." Walker, supra note 12 , at 62 . While fissile elements like plutonium can already be converted, the bulk of radioactive waste is not transmutable by any process yet known. See id.

${ }^{16}$ See Finn, supra note 9, at 640-41.

${ }^{17} \mathrm{See} i d$. at 623 . While all of the major nuclear nations are investigating deep geologic disposal, several nations are also actively considering seabed disposal. These nations include Canada, France, Japan, and the United Kingdom. See Carr Supports International Effort on Repository Performance Assessment, NUCLEARFUEL, Apr. 30, 1990, at 12.

${ }^{18}$ See infra text accompanying notes $28-37$. 
which we could dispose of all the things too dangerous or unpleasant to store or discard on land." ${ }^{19}$ The oceans have come to be seen as "the common heritage of mankind," and as such, a resource to be preserved, belonging exclusively to no country. ${ }^{20} \mathrm{SSD}$ does not fit easily into any of these evolving concepts of ocean use. Arguably, it is not "pollution" as contemplated by international antidumping accords. In fact, if the technology functions as it should, SSD prevents the massive pollution that could attend failed land storage or disposal.

This Comment analyzes the regulatory regime that would affect any SSD initiative, and it concludes that the present legal order is inadequate to ensure its safe development and implementation. Rather than proposing a ban on SSD, this Comment calls for the establishment of an international regulatory body to oversee its development and implementation. Part I provides an overview of the history and technology involved in SSD and explains its risks and advantages. Part II examines SSD's legality under current and developing sources of international law, including treaties and customary law. Part III outlines a proposal to establish an international regulatory body to oversee SSD's development and operation. Part IV concludes that a successful SSD regime could serve as a precedent for solving several other international environmental crises.

\section{SubSEabed Disposal of High-Level Nuclear WASte}

\section{A. History}

In contrast to most of the other waste disposal options, the concept of SSD originated in the academic scientific community, rather than by those in applied engineering or by bureaucratic sponsorship. ${ }^{21}$ As such, much of the technology and underlying

19 RESHAPING THE INTERNATIONAL. ORDER, supra note 2, at 40.

${ }^{20}$ See Third United Nations Conference on the Law of the Sea, opened for signature Dec. 10, 1982, U.N. Doc. A/CONJ., 62/122, reprinted in 21 INT'L LEGAL MATERIALS 1261 (1982) [hereinafter UNCLOS III]; see also infra note 77 and accompanying text (discussing the common heritage of mankind concept).

${ }^{21}$ See E. Miles, K. LEe, \& E. CARLin, Nuclear WASte Disposal Under the SEABED: ASSESSING THE POLICY ISSUES 23 (1985) [hereinafter E. MILES]. The academic rather than engineering or bureaucratic roots of the program "created an ambience in the SSD program radically different from that prevailing elsewhere in the U.S. radioactive waste effort. The program's principal strengths have been the disciplined skepticism of anonymous peer review, the inventiveness of academic 
assumptions of SSD are theoretical and largely unverified..$^{22}$ Since 1976, an international Seabed Working Group has worked under the auspices of the Nuclear Energy Agency (NEA) to determine the feasibility of SSD. ${ }^{23}$ The nations represented in the Group account for more than three quarters of worldwide installed nuclear capacity. Until 1986, much of the funding had come from the United States. ${ }^{24}$ However, as the U.S. began to focus exclusively on terrestrial disposal options, funding lapsed. As a result, the international research slowed substantially, and the initial phase of the NEA program was terminated three years prematurely. ${ }^{25}$ The NWPA amendments of 1987 provided for the formation of a "university-based Subseabed Consortium" and the Office of Subseabed Disposal Research within DOE responsible for coordinating investigation of SSD. ${ }^{26}$ Neither the Consortium nor the Office was provided with funding, and the U.S. effort has stagnated. ${ }^{27}$

\section{B. Technical Aspects}

It is important to outline the planned methodology of SSD, as much of the legal analysis turns on the choice of disposal method. While complex in practice, SSD centers around a simple idea. According to the theory of plate tectonics, the most stable geological formations on the earth's surface are the centers of the solid rock plates that constitute the planet's crust. ${ }^{28}$ Although the edges of the plates undergo constant collisions with neighboring plates,

entrepreneurs, and a natural inclination toward scientific collaboration across national boundaries." Id.

22 See id. at 26.

${ }^{23}$ See NuGlear ENERGy AgENCY, ORGanization For ECONOMIC CO-OPERATION AND DEVELOPMENT, SEABED DISPOSAL OF HIGH-LEVEL RADIOACTTVE WASTE: A STATUS REPORT ON THE NEA COORDINATED RESEARCH PROGRAMME 1 (1984) [hereinafter NEA].

${ }^{24}$ See E. MiLes, supra note 21, at 21.

${ }^{25}$ Only $20 \%$ of the research was complete at the time the U.S. withdrew funding. In phase one of the NEA project, an international team of scientists would have used data from field research to make an initial feasibility assessment by 1990 . See Baker, supra note 9, at 7-8. British, Italian, French, and Japanese research has continued on a smaller scale. See Marshall \& Hiruo, supra note 9, at 5.

${ }^{26}$ Pub. L. No. 100-203, tit. V, § 5063, 101 Stat. 1330-253 (1987) (codified at 42 U.S.C. § 10,204 (1988)). The Subseabed Consortium was to make its first report assessing SSD as an alternative waste disposal technology to Congress in 1990.

${ }^{27}$ See supra note 9 and accompanying text.

${ }^{28}$ See Hollister, A Review of Current Science and Technology for Disposal of High-Level Radioactive Wastes Within Geological Formations of the Deep Seabed, in NUCLEAR WASTE MANAGEMENT: THE OGEAN ALTERNATIVE 58-59 (T. Jackson ed. 1981). 
producing volcanoes, earthquakes, and other violent seismic activity, their centers remain undisturbed. This stable abyssal area is five to eleven kilometers below the surface of the ocean and is covered by a layer of clay sediment, deposited over many millions of years, which is tens to hundreds of meters thick. ${ }^{29}$ These areas are "marine deserts," gyres, or currents, flowing near the continental margins.

SSD would use the clays of the deep seabed as a medium for isolating HLW. The wastes would be rendered in a form that would delay dispersal within the sediment, packed into ballistic shaped metal "penetrometers" and transported by ship to the dump site. At the site, the containers would either be allowed to free fall into the ocean sediment, be propelled into place by an engine, or be placed into pre-drilled holes and capped. ${ }^{31}$ The last option would allow for easier retrieval should a problem develop with deployment or long-term disposal.

Exposed to the corrosive effects of salt water, the metal canister can be expected to last only for decades or perhaps centuriesmerely a fraction of the time necessary for safe isolation. ${ }^{32}$ After the primary waste barrier is breached, however, research shows that the surrounding seabed clay tends to immobilize or "sorb" ions found in radioactive wastes, trapping the radionuclides in place. ${ }^{33}$ Because of the plastic-like properties of the clay, the hole that the emplacement creates would seal itself. ${ }^{34}$ The deep sea clay is also highly impermeable, meaning that fluids travel through it extremely slowly. ${ }^{35}$ As a tertiary barrier, the vast water column would dilute

${ }^{29} \mathrm{See} i \mathrm{~d}$.

${ }^{30} \mathrm{See}$ id. at 59.

31 See NEA, supra note 23, at 107; Silva, Physical Processes in Deep-Sea Clays, 20 OCEANUS 31, 36-37 (1977).

${ }^{32}$ See E. MILES, supra note 21, at 28. There are varying estimates of the requisite isolation time. Congress's Office of Technology Assessment concluded that it would take about one million years for high-level waste from reprocessing 15-year-old spent fuel to fall below the toxicity of the original uranium ore. See OFFICE OF TECHNOLOGY ASSESSMENT, MANAGING THE NATION'S COMMERCIAL High-LEVEL RADIOACTIVE WASTE 29-30 (1985).

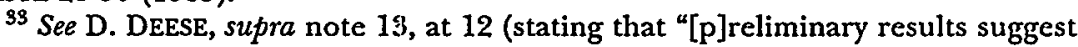
that about 1,000 to 10,000 times as much of the [radioactive] elements will be attached to sediment particles as are dissolved in adjacent pore water ${ }^{n}$ ).

${ }^{34}$ See NEA, supra note 23, at 117-18. Laboratory tests indicate that closure of a hole from a penetrating projectile would be immediate and total, whereas that of a hole left open by drilled emplacement would be gradual. See D. DEESE, supra note 13 , at 13 .

${ }^{35}$ See Hollister, supra note 28 , at 62 . Furthermore, the high heat (up to $250^{\circ}$ 
any escaped radionuclides, but planners view such contact with the biosphere as unacceptable isolation of the wastes. ${ }^{36}$

Because of the unique conditions that the insertion of wastes in the sea floor presents, the technology would have to be tested extensively in situ, rather than on the blackboard, before its merits can be fully assessed. ${ }^{37}$ Even so, certain advantages and risks are already apparent.

\section{LEGAL ANALYSIS}

Both treaty law and customary international law impose general international obligations upon states to protect the marine environment. The most important obligations in the SSD context derive from both the London Dumping Convention (LDG) ${ }^{38}$ and the Third United Nations Conference on the Law of the Sea (UNCLOS III). ${ }^{39}$

\section{A. The London Dumping Convention: "Dumping"}

The LDC of 1972, in force for fifty-six state parties including the United States, ${ }^{40}$ is a global attempt ${ }^{41}$ to ban or limit the dumping of specified pollutants into the marine environment. ${ }^{42}$ Its terms prohibit the dumping of all substances listed in Annex I of the Convention, the "black list" of pollutants. Annex II, the "grey list," catalogs a group of pollutants that may only be dumped subject to

celsius) of the wastes would not create convection currents in the sediment due to the tremendous pressure at depth, which prevents water from boiling. See E. MILES, supra note 21 , at 25.

${ }^{36}$ See E. MILES, supra note 21, at 28. This approach sharply contrasts with disposal of low level wastes, where dilution and dispersal with sea water is a primary objective.

${ }^{37}$ See D. DEESE, supra note 13, at 12 (enumerating unanswered empirical questions concerning the feasibility of SSD).

${ }^{38}$ Convention on the Prevention of Marine Pollution by Dumping of Wastes and Other Matter, Dec. 29, 1972, 26 U.S.T. 2403, T.I.A.S. No. 8165 [hereinafter London Dumping Convention].

${ }^{39}$ See UNCLOS III, supra note 20.

${ }^{40}$ See Moore, Considering an International Subseabed Waste Repository: Rational Choice and Community Interest, WASH. Q., Summer 1986, at 115, 119.

41 Article III (3) of the LDC defines "sea" as including "all marine waters other than the internal waters of States." London Dumping Convention, supra note 38, at 2407.

42 See Curtis, Legality of Seabed Disposal of High-Level Radioactive Wastes Under the London Dumping Convention, 14 OCEAN DEV. \& INT'L L. 383, 393. (1985) (stating that "[t]he basic philosophy of the LDC is that the nations of the world will work together to ensure that the marine environment becomes safe from the dangers of dumping"). 
the issuance of a prior permit by the flag state; all other dumping only requires the issuance of a prior general permit. ${ }^{43}$ High-level radioactive waste was classified as an Annex I pollutant, entirely banned from dumping under the LDC. ${ }^{44}$ The IAEA was charged with formulating the definitional distinctions between high and low level wastes. ${ }^{45}$

The question of whether SSD comes within the LDC's regulatory scheme turns on whether seabed emplacement of sealed canisters containing banned wastes constitutes "dumping" within article III 1(a); it defines the term as: "any deliberate disposal at sea of wastes or other matter from vessels, aircraft, platforms or other man-made structures at sea. ${ }^{46}$ The interpretation of the definition has proved to be an intensely divisive one for the contracting parties, and has engendered a substantial amount of academic commentary.

Upon the language of the definition, two possible constructions are possible. First, "disposal at sea"47 can be construed to refer only to the location of the dumping structure at the time of the dumping, independent of whether the material ever reaches the sea or not. The focus in this view is on the physical location of the dumping mechanism. ${ }^{48}$ Since SSD calls for delivery of the waste-

${ }^{43}$ See Letalik, Pollution from Dumping, in D. JOHNSTON, THE ENVIRONMENTAL LAw OF THE SEA 223 (1981). Annex III sets out factors that states are obliged to "carefully consider" in issuing permits.

${ }^{44}$ See London Dumping Convention, supra note 38, at 2465 (defining Annex 1 pollutants as " $[\mathrm{h}]$ igh-level radio-active wastes . . . defined on public health, biological or other grounds by the competent international body in this field, at present the International Atomic Energy Agency, as unsuitable for dumping").

${ }^{45}$ See 1978 IAEA Revised Definition, supra note 3. An Annex to this definition clarifies that deep disposal into the ocean comes within the terms of the definition:

The Definition identifies material, the radioactive content of which is at such a level that the Parties . . . would wish to prevent any participating State from issuing a special permit even after a detailed appraisal of the safety of the proposed operation, and even for the sector of the marine environment furthest removed from man, i.e. the deep sea with depth greater than 4000 met[er]s.

Id. at 840 (footnote and emphasis omitted).

${ }^{46}$ London Dumping Convention, supra note 38, at 2407.

${ }^{47}$ The meaning of "sea" is set out in the LDC, and is not a matter of contention. See supra note 41 . Wastes stored in the seabed in isolation from ocean waters quite clearly are not in the "sea." A different result would obtain for any SSD method that depended on dilution and dispersion in ocean waters once the primary sediment barrier is breached.

${ }^{48}$ Thus, under this conceptualization, "[e]ven the firing into space of rockets carrying waste would be covered ... provid[ed] the action started from a ship or similar structure outside the territorial waters of a State." Welsch, The London Dumping Convention and Sub-Seabed Disposal of Radioactive Waste, 28 GERMAN Y.B. OF 
bearing penetrometers from a vessel or platform based at sea, the LDC's article IV and Annex I would impose a complete ban upon the activity. ${ }^{49}$ Proponents of this construction point to the overriding purpose ${ }^{50}$ of the LDC that "permeate[s] the preamble, articles, and annexes of the LDC," which emphasizes, the interconnected nature of the marine environment. ${ }^{51}$ Further support for this construction can be found in the LDC's successful ban on ocean incineration, which seems to have been based on a location-at-sea definition. ${ }^{52}$

A second interpretation of article III focuses on the final resting place of the dumped material. A strong argument can be made that the repetition of the words "at sea" should be dispositive: since the second "at sea" refers unambiguously to the location of the dumping vehicle, the first "at sea" cannot also refer to the same thing; such a construction would be senselessly redundant. ${ }^{53}$ Under the Vienna Convention on the Law of Treaties, the context of the provision should be accorded primary importance; a more reasonable interpretation that gives ordinary meaning to each of the terms of the agreement is preferred unless it can be established that the parties intended otherwise. ${ }^{54}$ Several commentators have

INT'L L. 322, 326 (1985). Of course, wastes delivered to the seabed via a land-based tunnel should not fall within this interpretation of dumping. Sweden has implemented such a plan. See id. at 327.

${ }^{49} \mathrm{LDC}$ article IV provides in pertinent part: "In accordance with the provisions of this Convention Contracting Parties shall prohibit the dumping of any wastes or other matter in whatever form or condition except as otherwise specified below: (a) the dumping of wastes or other matter listed in Annex I is prohibited." London Dumping Convention, supra note 38, at 2408. For a description of Annex I wastes, see supra note 44.

50 See Curtis, supra note 42 , at 393.

51 Id. at 398. Curtis argues:

[T] he only harmonious and reasonable interpretation of "disposal at sea" is that which defines such disposal to mean the place where the dumping activities occur.... An interpretation which seeks to exempt seabed disposal from the LDC by . . . refer[ring] only to the "final resting place" ... directly conflicts with the Contracting Parties' broadly stated responsibilities to protect the marine environment from pollution caused by dumping. Any distinction between marine waters and the seabed and subsoil ... should be treated as artificial and inappropriate; wastes disposed of in the seabed are part of the marine environment.

Id.

52 See, e.g., Statement by the Norwegian Delegation to the Seventh Consultative Meeling, LDC 7/INF.22 (Feb. 17, 1983), quoted in Curtis, supra note 42, at 396.

${ }^{53}$ See Curtis, supra note 42 , at 396 (discussing the presence of redundancy within the four treaty languages); Moore, supra note 40 , at 129 (noting that a "strictly textual analysis . . . strongly supports an interpretation that [SSD] is not prohibited per se").

${ }^{54}$ Vienna Convention on the Law of Treaties, opened for signature May 23, 1969. 
attempted to resolve the controversy by comparing translations of the three other official language texts, and have reached varying conclusions. ${ }^{55}$ Thus, a facial reading of the definition of dumping yields no clear result. ${ }^{56}$

The contracting parties first attempted to resolve the ambiguity at the Seventh Consultative Meeting in February 1983, with inconclusive results. Norway raised the issue in light of the NEA Seabed Working Group's activities, and the parties resolved to call an intercessional meeting of legal experts to consider whether SSD fell within the scope of LDC. ${ }^{57}$ The experts were unable to reach agreement, but produced three draft resolutions.

At one extreme, the "Nordic" draft would have banned SSD outright unless a "future technical development" is proven to "secure the isolation [of HLW] from the biosphere." ${ }^{58}$ At the other extreme, the draft of the United Kingdom and France would have concluded that SSD falls outside of the LDC because it was unknown at the conclusion of the 1972 Convention. ${ }^{59}$ The United

U.N. Doc. A/CONF. 39/27, reprinted in 63 AM. J. INT'L L. 875, 885 (1969). Article 31 of that agreement provides that "[a] treaty shall be interpreted in good faith in accordance with the ordinary meaning to be given to the terms of the treaty in their context and in light of its object and purpose." Id. Moore notes that "[ $t]$ he Vienna Convention . . . is generally recognized today as the starting point in international law for the interpretation of agreements. Although the United States is not yet a party to that convention, it recognizes its provisions as customary international law." Moore, supra note 40 , at 128.

55 For example, Curtis explains that

[i]n the French text, "immèr:sion" (dumping) means "in the sea"; in Spanish, "vertimiento" means "in the sea"; and in Russian "Copoc" means "in the sea" or "into the sea." Thus, support for defining "at sea" to be the place where the disposal activities occur, in contradistinction to "in the sea," i.e., the final position of the wastes, is based in part on [which] authentic text $\ldots$ is used.

Curtis, supra note 42, at 396; see also Moore, supra note 40, at 129 (arguing that the more plausible reconciliation of the English version with the clear meaning of the other three languages is to adopt "the version that makes all three consistent with no changes in meaning in any language-that is, reference to final position of the materials disposed rather than location of the disposing vessel-should be preferred"); Welsch, supra note 48, at 325 (noting that the Spanish and English texts yield the same ambiguity, while the French text clearly means "disposal into the sea").

${ }^{56}$ See Welsch, supra note 48, at 327 (concluding after literal and contextual analysis that "[b]oth solutions appear possible").

${ }^{57}$ See Curtis, supra note 42 , app. at 404 (text of resolution $15(7)$ ).

${ }^{58}$ Welsh, supra note 48 , at 338 . Spain and Greenpeace International adopted a more radical position, arguing that SSD was per se prohibited by the Convention. Their efforts did not yield a draft resolution considered at the Eighth Consultative Meeting. See Moore, supra note 40, at 119-20.

${ }^{59}$ See Welsch, supra note 48 , at 338-39. 
States and West Germany adopted a middle position. They proposed that any method of SSD that did not harm the environment would be acceptable and that any future regulation should be based on "the specific technology applied." 60 In the end, the participants could not agree on a joint statement, and they concluded only that the LDC "is the appropriate international forum to address the question of [SSD]. ${ }^{" 61}$ After considerable debate on these positions, the Eighth Consultative Meeting of 1984 itself could not reach consensus on the legal issue, and only seconded the experts' jurisdictional conclusion. ${ }^{62}$

There was little substantive discussion of the issue until the Thirteenth Consultative Meeting in November of $1990 .{ }^{63}$ At this most recent Meeting, the contracting parties approved a proposal by Spain (the Spanish Resolution) providing that "[d]isposal of lowlevel radioactive wastes into sub-sea-bed repositories accessed from the sea constitutes a form of disposal . . . and is therefore suspended at present. $^{n 64}$ The Resolution clearly endorses the disposal vehicle interpretation ${ }^{65}$ of the article III 1(a) definition of "dumping." While its terms apply only to low-level waste, the Spanish Resolution impacts upon subseabed disposal of HLW as well. As noted, HLW has been classified as an Annex I pollutant, banned from "dumping" under the LDC. ${ }^{66}$ Thus, the new interpretation of "dumping" would also impose a ban on subseabed disposal of such waste. ${ }^{67}$

${ }^{60}$ Moore, supra note 40 , at 120.

61 Welsch, supra note 48 , at 339.

62 See Moore, supra note 40 , at 120 . The only addition was the following statement:

[N]o such disposal should take place unless and until it is proved to be technically feasible and environmentally acceptable, including a determination that such wastes and matter can be effectively isolated from the marine environment, and a regulatory mechanism is elaborated under the [LDC] to govern the disposal into the sea-bed of such radioactive wastes and matter.

Id.

${ }^{63}$ The only further action by the LDC potentially relevant to seabed emplacement issues was a 1989 decision to ban the scuttling of decommissioned nuclear submarines at sea. Over British protests, the LDC agreed that submarines do come within its 1983 moratorium on disposing of nuclear waste at sea. See Sub Dump Barred, NUCLEONICS WEEK, Nov. 23, 1989, at 16.

64 Resolution LDC.41(13), Disposal of Radioactive Wastes into Sub-Sea-Bed Repositories Accessed From the Sea (1990) [hereinafter Spanish Resolution] (emphasis added) (on file with the author).

${ }^{65}$ See supra notes $46-52$ and accompanying text.

${ }^{66}$ See supra text accompanying note 44 .

${ }^{67}$ See Spanish Resolution, supra note 64 . The second proviso envisions this result when it states in relevant part, " $\mathrm{R}$ [ecalling] that high-level radioactive wastes are listed 
It is important to note that the major nuclear nations-the United States, Britain, France, and the Soviet Union-voted against the proposal; Japan and three other nations abstained. ${ }^{68}$ The nuclear powers consider the Resolution non-binding, but indicated that they would comply voluntarily. ${ }^{69}$

Thus, after polarized negotiations, divisive voting, and much scholarship ${ }^{70}$ on the issue, the legal question appears to have been answered. This history raises doubts as to whether the LDC is the appropriate forum to regulate SSD. The parties' focus on the technical legal challenge to the exclusion of any substantive analysis of SSD-and failure to reach a consensus-is immediately striking. One observer has likened this narrow preoccupation with "disembodied texts" apart from the merits of the issue as "the kind of legal excess rightly condemned by Charles Dickens in Oliver Twist ...."71 Politics appears to have prevailed over scientific inquiry; it is instructive to note that the Convention deferred to legal experts rather than scientists in evaluating SSD.

Such an a priori regulatory approach necessarily fails to relate SSD to the larger waste disposal context. Any complete evaluation should proceed from the realization that the world's high-level wastes, already produced and awaiting permanent disposal in surface pools, must inevitably be disposed of in some medium. Waste disposal will likely be reduced to a choice between lesser

under Annex I to the London Dumping Convention, and therefore cannot be dumped at sea ...."Id.

${ }^{68}$ See Rubin, Industrial Powers Agree To Ban Ocean Dumping of Wastes, Associated Press Wire Service, Nov. 2, 1990.

69 See id. A British delegate to the Meeting made a statement after the vote that typified nuclear nation reaction to the voluntary moratorium: "[Y]ou just can't wish it away, we have to put [the radioactive waste] somewhere. We have no plans to dump radioactive waste, but we are not prepared to eliminate options that we may later regret." Id.

${ }^{70}$ For salient examples of the scholarship engendered by the question, compare Welsch, supra note 48 , with Curtis, supra note 42 . Both authors exhaustively analyze SSD's legality under the LDC, using the Vienna Convention as their basis for interpreting the text, yet reach opposite conclusions. Both authors focused on the same sources of interpretation, inter alia: context, plain meaning, legislative history, subsequent actions of the parties, and other official texts. Welsch ultimately concludes that "the disposal of radioactive wastes into the seabed in isolation from the biosphere does not come within the scope of the LDC." Welsch, supra note 48, at 353. However, Curtis concludes that this interpretation, as Article 32(b) of the Vienna Convention states, "leads to a result which is manifestly absurd or unreasonable." Curtis, supra note 42 , at 398 . Curtis's reasoning has previously been detailed. See supra note 55.

${ }^{71}$ Moore, supra note 40, at 116. 
evils, and the seabed may be the most environmentally sound location to store the wastes. Furthermore, waste disposal is inextricably linked to a myriad of other considerations besides ocean pollution. The LDC's aspiration to protect the oceans from environmental degradation is a noble one, but may make it an inappropriate organization to determine nuclear waste strategy. For example, it is beyond the scope of the Convention to consider such important "nonenvironmental community interests" as nuclear nonproliferation policy or developmental assistance for the third world. ${ }^{72}$

The LDC is not the detached and objective entity that could ultimately regulate the complex operational aspects of SSD. At the projected rate of spent nuclear fuel generation, by the year 2000, emplacement will have to take place at a rate of one waste penetrometer per hour, 24 hours per day, 365 days a year in order to dispose of the waste adequately. ${ }^{73}$ There will be no opportunity for trial and error. Clearly, the oversight of such an operation will require engineering and technical skills. At present, there is no precedent for an international organization with the enforcement powers and know-how to manage SSD. The LDC, with its exceptionally political and narrowly legal focus, will not be the appropriate body to oversee implementation of SSD.

\section{B. The Third Conference on the Law of The Sea}

In the year following completion of the LDC, negotiations began on what was to result in the largest and most comprehensive multilateral agreement concluded by states: the Third United Nations Conference on the Law of the Sea. To date, UNCLOS III has been signed by 155 countries and ratified by $42 ; 7^{74} 60$ countries

${ }^{72}$ Id. at 121. Professor Moore argues that an international subseabed repository would substantially simplify the monitoring of the back end of the nuclear fuel cycle, helping to prevent horizontal proliferation of nuclear weapons. See id. at 123. SSD would also allow developing countries "to participate fully in civilian nuclear power development." Id. at 125. While operation of nuclear power plants might be within the capabilities of such nations, waste disposal presents a problem that even the most technologically advanced nations have been unable to solve. Poorer nations with existing nuclear facilities will find it difficult to engineer and build a multi-billion dollar waste repository and might be tempted to engage in unsafe disposal practices. See id.

73 See E. MILES, supra note 21, at 27.

74 See Training Programme for Enterprise to Be in Place by 1991, UN CHRONICLE, June 1990, at 38, 39. 
must ratify the treaty to bring it into force. ${ }^{75}$ A number of states crucial to the success of UNCLOS III, including the United States, have refused to sign or ratify the document, largely due to the deep seabed resource provisions of the agreement. ${ }^{76}$ UNCLOS III set out to establish a kind of constitution for the oceans. Its primary focus is an accommodation between the economic interests of coastal states in their own waters and the interests of the international community in safeguarding the rights of free navigation. The most significant parts of the Convention in the SSD context are those pertaining to establishment of a seabed regime for extracting resources and protecting the marine environment. Although SSD is not specifically addressed under UNCLOS III, its provisions are highly relevant to SSD's legality and eventual operation.

\section{The International Seabed Authority and "Appropriation" Issues}

UNCLOS III's most unique and controversial provisions relate to the establishment of an International Seabed Authority (ISA) to govern the mining of deep seabed manganese nodules and other minerals. Declaring these resources to be "the common heritage of mankind," $" 77$ the convention states that "[n]o State shall claim or

75 See UNCLOS III, supra note 20, art. 308(1).

${ }^{76}$ For a comprehensive statement and defense of the U.S. position, see Malone, The United States and the Law of the Sea After UNCLOS III, LAW \&c CONTEMP. PROBS., Spring 1983, at 29 (1983). Mr. Malone, chair of the U.S. Delegation to the Conference, argues that the nonseabed provisions of UNCLOS III, including the marine protection provisions, merely codify existing customary law. See id. at 33 . He argues that the objectionable deep seabed mining provisions would create a "socialist" order by establishing the International Seabed Authority, a bureaucracy that would govern resource extraction of the areas beyond national jurisdiction, and mandate income and technology transfer to lesser developed nations. Id. at 31-32. See also President's Statement, U.S. Department of State, Current Policy No. 416, at 1-2 (JulyAug. 1982) (noting U.S. objections to the seabed regime).

There has been substantial commentary on the advisability of and prospects for U.S. ratification of UNCLOS III. See, e.g., Clingan, The United States and the Law of the Sea Conference, in THE New ORder of The OcEans: The Advent of A Managed Environment 219, $234-37$ (G. Pontecorvo ed. 1986) [hereinafter Pontecorvo]. President Bush has signaled no departure from the original U.S. position, and has refused even to send an observer to Preparatory Commission negotiations currently underway. See A Bigger Sea Around Us, N.Y. Times, Jan. 7, 1990, at A26, col. 1; Hearing of the Senate Foreign Relations Committee, Sept. 20, 1990 (LEXIS, NEXIS library, Fednew file) (testimony of Thomas Pickering, U.S. Ambassador to the United Nations) (explaining the Bush Administration's refusal to take part in PrepCom negotiations).

77 UNCLOS III, supra note 20, art. 136. This doctrine derives from Arvid Prado, an Italian Ambassador to the United Nations, and was first applied to the seabed in the U.N. Declaration of Principles Governing the Seabed and the Ocean Floor and the Subsoil thereof, beyond the limits of National Jurisdiction in 1970. Its precise 
exercise sovereignty or sovereign rights over any part of the Area or its resources, nor shall any State or natural or juridical person appropriate any part thereof."78 "The Area" is defined broadly to include "the seabed and the ocean floor and subsoil thereof, beyond the limits of national jurisdiction. ${ }^{79}$

Since the ISA governs activities occurring within the broad expanse of "the Area," SSD would appear to fall within activities regulated by the its jurisdiction. It would certainly take place in the Area, and theoretically has the potential for being a prohibited "appropriation" of the seabed. There are, however, two difficulties with this reasoning.

First, the convention defines "activities in the Area" to be "all activities of exploration for, and exploitation of, the resources of the Area." ${ }^{80}$ Given the definition of "resources" in article 133(a) as "all solid, liquid or gaseous mineral resources in situ in the Area at or beneath the seabed, including polymetallic nodules," the ISA's jurisdiction seems confined to mineral extraction. Although it may be argued that the seabed itself is a "resource," which SSD exploits, the argument is strained. ${ }^{81}$ The convention was well aware of the $\mathrm{SSD}$ option at the time the seabed regime was negotiated, ${ }^{82}$ yet

meaning is a matter of controversy, but generally it is understood as the theoretical underpinning for rejecting both the res nullius (subject to national appropriation) and the res communis (not subject to appropriation, but open to access and use by all) concepts of the seabed ownership. Rather, exploitation of the "common heritage" should benefit all mankind and be shared equitably. The ISA's ostensible mandate is to realize this last goal. See Schachter, Concepts and Realities in the New Law of the Sea, in Pontecorvo, supra note 76, at 27, 51-53.

78 UNCLOS III, supra note 20 , art. 137(1).

${ }^{79} I d$. art. 1(1).

${ }^{80}$ Id. art. I(3).

81 When presented with this argument during a symposium on SSD, Elliot Richardson, a U.S. Ambassador to UNCLOS III responded:

I don't believe the [ISA] could [assert jurisdiction over SSD] because its jurisdiction would be limited to the control and management of the exploration of deep seabed resources. The exploitable resources of the deep seabed would come within its jurisdiction as distinguished from the resources of the water column above the seabed.... The Authority could apply and enforce ... standards as against a company involved in deep seabed mining, even to the point of forcing the company to stop a mining operation because of new evidence that its activity was significantly destructive of the marine environment.... [I]t doesn't follow that an authority set up only to manage the exploitation of seabed resources and to protect the marine environment from the consequence of such exploitation could protect the seabed generally.

Richardson, Sub-Seabed Disposal in the Context of the Law of the Sea, in NUCLEAR WASTE MANAGEMENT: THE OCEAN ALTERNATIVE, supra note 28, at 87-88.

${ }^{82}$ SSD first gained recognition in the scientific community in 1973. Delegates to 
defined the scope of the ISA in terms that particularly describe mining operations. Moreover, while the drafters meticulously delineated the operational aspects of a mining regime, including provisions for "pioneer investors" and an "Enterprise," these sections are silent on any regime that could manage SSD. ${ }^{83}$

Second, it is not clear that seabed emplacement would constitute an exercise of sovereignty or appropriation prohibited by article 137(a). SSD might better be considered a reasonable "use," rather than an attempt to appropriate. ${ }^{84}$ According to one estimate, the area occupied by a repository would amount to a loss of only $0.0005 \%$ in area available for mining operations. ${ }^{85} \mathrm{SSD}$ sites could be located away from potential mineral recovery areas; depending on the eventual form of SSD, there is even the possibility that mineral resources on the sea floor or shallow sediment could be recovered without endangering the repository. ${ }^{86}$ Thus, it is difficult to conclude that SSD interferes with UNCLOS III's seabed regime, or its basis in the "common heritage of mankind."

At most, UNCLOS III requires consultation with the ISA concerning emplacement activities. Article 147(3) imposes the obligation that "[o]ther activities in the marine environment shall be conducted with reasonable regard for activities in the Area." In addition, article 145 gives the ISA broad rulemaking powers to protect the marine environment from the harmful effects of drilling, construction, excavation, and the like in the Area. ${ }^{87}$ UNCLOS III

UNCLOS III were aware that SSD was being debated in "other forums," and did not consider the subject during the negotiations. See id. at 85-86.

${ }^{83}$ See UNCLOS III, supra note 20, arts. $150-53$ \& resolution II.

84 There are "uses" of the sea floor that are considered freedoms of the high seas. For example, article $87(1)(c)$ includes the "freedom to lay submarine cables and pipelines" together with the traditional freedoms of navigation, overflight, and fishing. These freedoms are essentially those recognized in 1958 by article 2 of UNCLOS I. See Convention on the High Seas, Apr. 29, 1958, 13 U.S.T. 2313, T.I.A.S. No. 5200, 450 U.N.T.S. 82. Although submarine cables might be considered a physical appropriation of a part of the sea floor, they are not considered as such under international law. Instead they constitute a reasonable use of the sea floor.

${ }^{85}$ See E. MILES, supra note 21, at 79-80 (quoting Hinga, The Conflicts Between Deep Ocean Mining and Subseabed Disposal of Radioactive Wastes (Sandia Nat'l Laboratories, Report No. SAND81-1486J) (unpublished manuscript)).

${ }^{86}$ See Finn, supra note 9 , at 682.

${ }^{87}$ For instance, UNCLOS III provides that the Authority shall adopt appropriate rules ... for inter alia:

(a) the prevention, reduction and control of pollution ... from harmful effects of such activities as drilling, dredging, excavation, disposal of waste, construction and operation or maintenance or installations .... 
would obligate nations to ensure that the operational aspects of SSD do not unreasonably restrict mineral recovery or harm the marine environment.

To a large extent, friction between the ISA and SSD regimes would only come about if UNCLOS III comes into force without the ratification of the major nuclear nations. A prevailing theme of the deep sea mining negotiations was the demand of developing nations to share in the wealth and technology of seabed resource recovery. ${ }^{88}$ The Group of 77, a bloc of less developed countries, rallied behind the common heritage of mankind concept, and viewed the seabed mining regime as an opportunity to establish a New International Economic Order. ${ }^{89}$ The Group encountered fierce resistance from developed nations, which have refused to sign or ratify UNCLOS III because of its objectionable "socialist" redistribution and regulation provisions. ${ }^{90}$ If the major nuclear nations do not support UNCLOS III, there will be a greater tension between seabed emplacement and ISA jurisdiction. Just as the Group of 77 does not necessarily have a single opinion of nuclear power, there is no unified front on SSD. ${ }^{91}$ Many third world nations view nuclear power as a key to development, and would depend on an international repository to dispose of their nuclear waste. ${ }^{92}$ If developed non-signatories proceed with emplacement outside of the ISA, SSD would tend to be unnecessarily cast into a developed/less developed "appropriation" issue.

(b) the protection and conservation of the natural resources of the Area and the prevention of damage to the flora and fauna of the marine environment. UNCLOS III, supra note 20, art. 145. From the context of its usage here, the term "disposal of waste" seems to point clearly to wastes generated in resource recovery.

${ }^{88}$ The developing nations' influence has been well documented. See, e.g., Beesley, The Negotiating Strategy of UNCLOS III: Developing and Developed Countries as PartnersA Pattern for Future Multilateral International Conferences?, LAW \& CONTEMP. PROBS., Spring 1983, at 183, 185-93 (documenting North/South interactions during the negotiation of UNCLOS III).

${ }^{89}$ For a detailed analysis of the New International Economic Order, see RoLSON, U.S. FOREIGN POLICY AND THE NEW INTERNATIONAL ECONOMIC ORDER: NEGOTIATING GLOBAL PROBLEMS, 1974-1981 (1981).

${ }^{90}$ See, e.g., Malone, supra note 76, at 31 (noting the objections of the United States to UNCLOS III).

91 See E. MILES, supra note 21, at 76.

92 See supra note 68 and accompanying text; see also D. DEESE, supra note 13 , at 151 (noting ambivalent attitudes of lesser developed nations toward waste disposal in the global commons). 


\section{Protection and Preservation of the Marine Environment}

UNCLOS III delineates the rights and duty of all States to protect and preserve the marine environment. Its articles are intended to establish constitutionally the importance of safeguarding the oceans: they prescribe broad norms of State behavior as to both dumping and control of marine pollution. ${ }^{93}$

UNCLOS III adopts the LDC's definition of dumping ${ }^{94}$ verbatim, with one crucial difference: the first ambiguous reference to "at sea" in the LDC's definition is deleted. "Dumping" is defined as "any deliberate disposal of wastes or other matter from vessels, aircraft, platforms or other man-made structures at sea." 95 The language leaves no doubt that the definition of dumping depends not on the final resting place of the wastes, but rather the location of the dumping vehicle. SSD would clearly be considered dumping under UNCLOS III, which puts an obligation on States to "take... all measures ... necessary to prevent, reduce and control pollution of the marine environment from any source ...."96 Such measures must "minimize to the fullest extent possible . . . the release of toxic, harmful or noxious substances, especially those which are persistent ... from or through the atmosphere or by dumping." 97 Radioactive wastes, if released into the biosphere, are unequivocally "pollution," $" 98$ and are the most persistent wastes known to mankind. As a result, States under the convention appear to have an affirmative duty to prohibit SSD unless it can be shown that

${ }^{93}$ See UNCLOS III, supra note 20, arts. 192-96.

94 See supra text accompanying note 46.

${ }^{95}$ UNCLOS III, supra note 20 , art. 1(5)(a)(i).

${ }^{96} I d$. art. 194(1).

97 Id. art. 194(3)(a) (emphasis added).

${ }^{98}$ See id. art. 1(4). The Convention adopts the broadest definition of "pollution" found in international law. Sec Tomczak, The Definitions of Marine Pollution: A Comparison of Definitions Used by International Conventions, 8 MARINE POL'Y 311, 322 (1984). It is defined as:

$[T]$ he introduction by man, directly or indirectly, of substances or energy into the marine environment . . . which results or is likely to result in such deleterious effects as harm to living resources and marine life, hazards to human health, hindrance of marine activities, including fishing and other legitimate uses of the sea, irnpairment of quality for use of sea water and reduction of amenities.

UNCLOS III, supra note 20, art. 1(4). Thus, seabed emplacement of sealed penetrometers that may eventually breach the sediment layer might be considered "pollution," even if there is only some undefined probability that the event will occur. The risk of breach will have to be viewed under the "likely to result" standard set out in the definition. 
radionuclides will not escape sedimentary isolation and enter the environment. UNCLOS III thus appears to clarify and extend the LDC's requirements, pioneering more protective provisions.

The foregoing obligation, however, might be substantively the same as that mandated by the LDC. In large measure, UNCLOS III delegates the actual business of regulation and standard-setting to "competent international organizations" such as the LDC, with enforcement left to coastal or flag states. ${ }^{99}$ This tends to create a "facing mirrors" problem: both the LDC and UNCLOS III look to each other for guidance in dealing with seabed emplacement issues. The LDC in theory should find its mandate in UNCLOS III's provisions. Those provisions do not come into play unless the LDC determines that "enforcement" is necessary when viewed against those same UNCLOS III provisions. In practical effect, this means that the very same finding of environmental risk that would bring emplacement under the LDC would also bring it under UNCLOS III. Conversely, if it were determined that no environmental risk were posed by SSD, neither international agreement would apply. ${ }^{100}$ Thus, in the emplacement context, UNCLOS III's dumping provisions are more like declarations of broad principle rather than enforceable obligations on states. The Convention's dumping articles are important and relevant to the SSD debate, but are more hortatory than binding.

Some nations, including the United States, view the convention's marine protection provisions as merely codifying customary international law. ${ }^{101}$ The chair of the U.S. delegation to the conference, James L. Malone, asserts that "[f]or the marine

99 As far as enforcement with respect to pollution by dumping, UNCLOS III provides that

[1]aws and regulations adopted in accordance with this Convention and applicable international rules and standards established through competent international organizations or diplomatic conference for the prevention, reduction and control of pollution of the maritime environment by dumping shall be enforced:

a) by the coastal State with regard to dumping within its territorial sea or its exclusive economic zone or onto its continental shelf;

b) by the flag State with regard to vessels flying its flag or vessels or aircraft of its registry;

c) by any State with regard to acts of loading of wastes or other matter occurring within its territory or at its off-shore terminals.

UNCLOS III, supra note 20, art. 216(1).

${ }^{100}$ See Richardson, supra note 81, at 85-86.

101 See Malone, supra note 76, at 29; Schachter, supra note 77, at 40. 
environment, the Convention is unnecessary. Existing international conventions provide adequate standards restricting the discharge of pollutants ...." ${ }^{n 102}$ Under this conception of UNCLOS III, the treaty creates no additional obligations. The rights and duties of both signatories and nonparties to the agreement remain unchanged.

\section{Failure of UNCLOS III to Resolve Emplacement Issues}

Given the foregoing analysis, UNCLOS III ultimately holds little promise as a control on the development and implementation of seabed emplacement. The ISA's jurisdiction is not likely to extend to SSD. A challenge based on an "appropriation" claim is also likely to prove unavailing. The controversy over whether UNCLOS III actually creates any new environmental protection obligations undermines any claim that it in and of itself makes SSD illegal.

In addition, UNCLOS III's applicability must turn on evaluations of technology, rather than a priori legal reasoning. As noted, the negotiating states knew of the emplacement option, but chose neither to ban nor to sanction it. ${ }^{103}$ It would be inappropriate to read into the language, ex post facto, an intent to do either. Narrow legal interpretation of UNCLOS III, apart from a consideration of the option's merits, suffers from the same problematic focus as has characterized the LDC's consideration of the issue. ${ }^{104}$ Further, both agreements fail to provide adequate mechanisms to conduct the requisite initial scientific evaluations and regulate the operational aspects of seabed emplacement.

\section{Customary International Law}

Customary international law ${ }^{105}$ represents a final potential restraint on SSD, although determining the precise contours of such limitation is difficult. Neither SSD nor any similarly hazardous subseabed activity has ever been undertaken, and there are no unequivocal state practices demonstrating the requisite material act

102 Malone, supra note 76, at 36.

${ }^{103}$ See supra note 82 and accompanying text.

104 See supra notes 70-73 and accompanying text.

105 Customary law has been described as "any recurring mode of interaction among individuals and groups, together with the more or less explicit acknowledgment by these groups and individuals that such patterns of interaction produce reciprocal expectations of conduct that ought to be satisfied." R. UNGER, LAW IN MODERN SOCIETY 49 (1976). 
and opinio juris. ${ }^{106}$ However, there are several accepted norms of state behavior that will impact on SSD.

In contrast to a previous international presumption that pollution of the ocean beyond national jurisdiction was legal unless affirmatively prohibited by treaty, ${ }^{107}$ the current rule is founded upon the notion that all uses of the high seas must be exercised "with due regard for the interests of other States." 108 Accordingly, states have an obligation to determine whether a proposed use of the ocean, undertaken under authority of a high seas freedom, ${ }^{109}$ is "reasonable" before proceeding. ${ }^{110}$ McDougal and Burke, commentators who have done much to elaborate upon this international law requirement, have noted the following criteria to evaluate the reasonableness of a proposed waste disposal plan:

Factors relevant to an assessment for this purpose would include the scope and intensity of prior investigation of a proposed site, the possibility of harm according to existing information, prior use of the area, effects on such prior use and on potential uses, and available alternatives for the disposing state. ${ }^{111}$

Applied to SSD, this test yields ambiguous results. Emplacement will only be reasonable if it is safe "according to existing information," the disposing state essentially has no other viable options, and the relative importance of competing uses is low. Yet, the major difficulty in evaluating any HLW disposal plan exactly is the inability to assess each of these variables. Most importantly, it is difficult to

${ }^{106}$ In order to establish a rule of customary international law, it is not enough merely to demonstrate that a state or group of states has acted in a particular way. There must also be a showing that the relevant participants thought of themselves as bound to act in the way they did, for other than moral or political reasons. See $\mathrm{M}$. SHAW, INTERNATIONAL LAW 70 (2d ed. 1986) ("The opinio juris, or belief that a state activity is legally obligatory, is the factor which turns the usage into a custom and renders it part of the rules of international law."); see also Haimbaugh, Protecting the Seas from Nuclear Pollution, 33 S.C.L. REv. 197, 222 (1981) ("In the few decades during which nations have faced problems of handling and disposing of radioactive wastes, little or no customary international law has crystallized to define the authority of states to deal with these problems.").

${ }^{107}$ See B. SMITH, STATE RESPONSIBILITY AND THE MARINE ENVIRONMENT 90 (1988) (noting superseded rule of customary international law that the right to dispose of waste materials in the high seas is a traditional freedom of the seas).

${ }^{108}$ UNCLOS III, supra note 20 , art. 87(2).

${ }^{109}$ See supra note 84.

110 The London Dumping Convention's annex system of prohibition and permitting is strong evidence of the presumption against pollution. The Convention essentially engages in a determination of "reasonableness" in classifying pollutants. See supra notes $42-45$ and accompanying text.

11 M. MCDOUgal \& W. BURKe, The PUblic ORder of The Oceans 863 (1962). 
determine if the technology will remain safe for the many thousands of years necessary to prevent harm to the environment. Again, the legal analysis must turn entirely on technological evaluations. States may plausibly argue the reasonableness issue either way, depending on the science they choose to accept. A state that undertakes SSD will no doubt consider it a reasonable use of the oceans, and thus a high seas freedom. Thus, the requirement imposes little practical limitations on SSD, unless the option is patently unsafe-in which case the disposing state would most likely not attempt it anyway.

Related to the foregoing requirement is the evolving concept that states have an obligation to protect and preserve the marine environment. Like the reasonableness requirement, there is little debate that this duty has become a rule of customary international law. ${ }^{112}$ The rule has found its most concrete expression in part XII of UNCLOS III, which expressly imposes the obligation on all states and requires them to take measures "to prevent, reduce and control pollution of the marine environment." 113 As UNCLOS III here purports to be codifying customary law, ${ }^{114}$ the same observations made in the previous discussion of UNCLOS III's obligations apply equally to this analysis: ${ }^{115}$ most of the marine protection provisions are advisory in nature; they rely on other international forums for definition and implementation. ${ }^{116}$ The obligation's genesis in customary law, however, is important because the rule is binding on all states, even non-ratifiers of the Convention, and thus may restrain unilateral action by states outside of the treaty regime.

112 See B. SMITH, supra note 107 , at 94 (concluding that " $[\mathrm{t}]$ he overwhelming opinion of contemporary authors appears in accord with the view that the obligation to prevent material injury to the high seas environment has achieved customary legal status"); see also RESTATEMENT (THIRD) OF FOREIGN RELATIONS LAW OF THE UNITED STATES $§ 601$ (1986). The Restatement provides:

(1) A state is obligated to take such measures as may be necessary, to the extent practicable under the circumstances, to ensure that activities within its jurisdiction or control ... .

(b) are conducted so as not to cause significant injury to the environment . . . of areas beyond the limits of national jurisdiction

Id.

113 UNCLOS III, supra note 20, art. 194(1).

114 See supra notes 101-02 and accompanying text.

115 See supra notes 93-102 and accompanying text.

${ }^{116}$ See id,; see also Charney, The United States and The Law of the Sea After UNCLOS III-The Impact of General International Law, LAW \& CONTEMP. PROBS., Spring 1983, at $37,42$. 
In the end, customary international law does not represent much of a limitation on SSD. In the absence of a strong regulatory regime, those states with an interest in carrying out an SSD initiative will be able to do so, and will influence the development of customary law to accommodate this result. De Visscher analogized the growth of customary international law to the gradual formation of a road across vacant land. ${ }^{117}$ While several directions initially are followed, the majority of users begin to follow the same line which becomes a single path. "Not long elapses before that path is transformed into a road accepted as the only regular way . . . "118 During this development, some make heavier footprints than others because of their greater weight,

thus the more influential states ... mark the way with more vigour and tend to become the guarantors and defenders of the way forward.... This follows from the nature of the international system where all may participate but the views of those with greater power carry greater weight.... Universality is not required [to establish a new customary rule], but some correlation with power is. ${ }^{119}$

In the SSD context, the major nuclear states are also those states that leave heavy footprints. ${ }^{120}$ If a coalition develops among them to begin SSD, that event will impact on the creation of customary law, rather than vice versa. At best, customary international law will require that SSD be carried out in the most environmentally sound manner, and may limit unilateral action by those states either outside of the LDG-UNCLOS III treaty regime, or who refuse to comply with the LDC's non-binding ban on SSD.

117 See M. SHAW, supra note 106, at 65 .

${ }^{118} I d$.

119 Id. at 65-67 (emphasis added).

${ }^{120}$ The states that participated in the original NEA Seabed Working Group were Belgium, Canada, France, the Federal Republic of Germany, Italy, Japan, the Netherlands, Switzerland, the United Kingdom, and the United States. See Moore, supra note 40 , at 118. Not coincidentally, nuclear power accounts for more than $25 \%$ of electricity generated in four of these states: France, Japan, the Federal Republic of Germany, and Canada. See id. at 121. States with nuclear weapon production capability have an added incentive to pursue a seabed emplacement initiative. If all or even several of these states decide to pursue seabed emplacement, it is difficult to imagine any relevant rule of customary international law imposing serious constraints on the undertaking. 


\section{REGIME ${ }^{121}$ DESIGN AND CREATION: MANAGED NUClEAR WASTE IDISPOSAL IN THE OCEAN}

The international response to seabed emplacement to date has been inadequate. While certain governing principles are apparent, the international status of SSD remains ambiguous. Evaluation of the option has proceeded piecemeal, and has largely focused on how SSD fits under existing organizational structures rather than whether those systems are appropriate to the question. Such a legal vacuum opens the door to unilateral or small group "reciprocal" state action, and creates a lack of uniform technical standards. Seabed emplacement is too important an issue to fall through the interstices of international regulation: short of nuclear war, it is potentially the most environmentally destructive endeavor undertaken by humankind, with the most irreparable and long-lived consequences. Conversely, it might be the only feasible solution to the immediate and seemingly intractable problem of high-level waste disposal. This is not an issue like seabed mining, where the international community enjoys the luxury of perfecting the ideal regime far in advance of anticipated need. ${ }^{122}$ The consequences of either an international stalemate or a trial and error approach are too serious.

\section{A. The Need for a New Regime}

One may legitimately question the need for the creation of yet another regime to govern seabed emplacement. There are more than 150 multilateral environmental conventions currently in force, most recently negotiated and replete with their own complex operational machinery. ${ }^{123}$ Existing institutions already possess a

${ }^{121}$ Professor Ernst Haas's definition of regime is highly relevant to the following discussion:

Regimes are norms, procedures, and rules agreed to in order to regulate an issuearea. Norms tell us why states collaborate; rules tell us what substantively speaking, the collaboration is about; procedures answer the question of how the collaboration is to be carried out. Procedures, therefore, involve the choice of whether specific administrative arrangements should be set up to regulate the issue area. Administration involves organization.

Haas, Why Collaborate? Issue-Linhage and International Regimes, 32 WORLD POL. 357, 397 (1980).

${ }^{122}$ As noted, international development of the International Seabed Authority has taken enormous amounts of diplomatic time and effort. The economic viability of its raison d'être, seabed mining, is still decades in the future.

${ }^{123}$ See von Moltke, International Commissions and Implementation of International 
measure of legitimacy, based upon a pre-existing mandate. ${ }^{124}$ They sometimes have considerable power which can be brought to bear on a given environmental problem. ${ }^{125}$ However, no existing regime has a sufficiently clear mandate or appropriate operational philosophy to manage SSD.

There are at least nine organizations that may claim to regulate some or all of seabed emplacement activities. ${ }^{126}$ As one observer noted, "[a]t the global level interorganizational conflicts over program priorities and possibilities for task expansion are endemic because the funds to support international collaboration are small, sunk costs are great, and executive heads perceive themselves being caught in a zero sum game." 127 SSD impacts on a very large number of international concerns. There is a high potential for conflict when several organizations, each with its own agenda and constituency, attempt to exert a measure of control over SSD. "Turf wars" of this sort tend to undermine legitimacy and destroy consensus. No coherent regulatory structure will likely emerge from this disarray.

As was shown in Part II, even organizations whose mandate appears strongest in this area have been unable to formulate a satisfactory approach to the emplacement issue. The LDC debates have produced little of substance. The Convention's consideration has been limited to legalistic "yes or no" interpretation, and underlying political considerations, rather than solid scientific evidence, have motivated many of the members' positions. Perhaps more distressing is that the bodies responsible for the LDC's crucial

Environmental Law, in INTERNATIONAL ENVIRONMENTAL DIPLOMACY 87, 89 (J. Carroll ed. 1988).
124 See id. at 88.
${ }^{125} \mathrm{Id}$.
126 The potential players in an SSD regime might include:
1. The signatories to the London Convention
2. The International Atomic Energy Agency (IAEA)
3. The Intergovernmental Oceanographic Commission (IOG)
4. The United Nations Environment Programme (UNEP)
5. The interorganizational Group of Experts on the Scientific Aspects of Marine Pollution (GESAMP)
6. The International Maritime Organization (IMO)
7. The World Health Organization (WHO)
8. The International Seabed Authority (ISA)-if UNCLOS III enters into force.
9. The Nuclear Energy Agency (NEA) of the OECD.

See E. MILES, supra note 21, at 90.

${ }^{127}$ Id. at 89. 
scientific advice and management, the NEA and the IAEA, have very limited goals and perspectives. Generally, they treat cooperative waste management as "a problem that inhibits nuclear energy development." ${ }^{\text {128 }}$ The IAEA's usual activity in nuclear safety and environmental concerns is limited to preparing various codes and guides, rather than active leadership of the kind necessary for a subseabed regime. Further, one observer has noted the apparent NEA attitude that "it does not really matter if each country establishes its own criteria and standards for radioactive waste management without international oversight."129 Such qualities make these organizations poor foundations for an international SSD management regime. Near total revision of their roles would be a prerequisite for possible service in that capacity. A new regime with a clear mandate and appropriate operative philosophy is imperative.

\section{B. General Concerns for the New Regime}

The touchstone of any appropriate SSD regime will be its ability to evaluate and implement the appropriate technology. Nuclear waste disposal is unique among global environmental problems because of its inherent permanence: decisions made in the next decade will affect mankind for at least 10,000 years, and perhaps up to a million years. ${ }^{130}$ Unlike oil spills and other transboundary environmental problems that are adequately regulated with comprehensive liability schemes, seabed emplacement-or any permanent HLW disposal technology-must work correctly the first time, and remain functioning for a time span even longer than history has been recorded. Thus, it is impossible to rely on a form of ongoing oversight to protect the environment: the waste elements will outlast even our most permanent institutional

128 D. DEESE, supra note 13, at 162.

${ }^{129} \mathrm{Id}$.

130 To secure Nuclear Regulatory Commission approval, the Yucca mountain terrestrial repository must be designed to achieve complete isolation from the biosphere for at least 10,000 years. See supra text accompanying note 11 . The former chairman of the Committee on Radioactive Waste Management of the National Academy of Sciences stated that " $[\mathrm{h}]$ igh-level nuclear wastes are extremely toxic, with some fission product radionuclides having effective lifetimes of more than a million years." Frosch, Disposing of High-Level Radioactive Waste, 20 OcEaNUS 5,5 (1977). Another expert agrees that " $[t]$ he level of radioactivity and rate of decay of the full suite of elements is such that the waste elements must not be allowed to escape from the seabed for a million years." Silva, Physical Processes in Deep-Sea Clays, 20 OCEANuS 31,31 (1977). 
arrangements. As an example, planners at Yucca mountain are finding it difficult to devise a way to warn generations far in the future of the site, as no language has lasted even close to the time period needed. ${ }^{131}$ Engineering and siting permanent warning signs is itself a serious challenge. ${ }^{132}$ Nation-states, and even more ephemeral international organizations, cannot be relied upon to "manage" SSD's environmental risk in the traditional sense. Instead, the technology must be self-regulating; any system must be designed to isolate waste without relying for its effectiveness on human supervision and intervention. ${ }^{133}$

\section{Involving the Appropriate Actors}

The new regime must focus on developing, selecting, and implementing the right technology. This entails the establishment of a treaty regime among interested states that vests power in the relevant technical elites, rather than in the traditional hands of diplomats and lawyers. Deferring to scientists in such a major way would be a first in international environmental problem-solving, but is crucial in the SSD context if the process is to remain as depoliticized as possible. One self-proclaimed "neo-functionalist" commentator has pointed to the involvement of such actors as a primary factor in the success or failure of international environmental agreements:

It is virtually impossible to make an effective contribution to marine pollution treaty-making without possessing ... a sophisticated understanding of the technologies related to the problem of marine pollution and to the alternative solutions available .... One would wish to back "los tecnicos" in their constant, if understated, struggle with "los politicos" ....

[S]uccess in marine pollution diplomacy depends essentially on the political skills of the appropriate technical elites. ${ }^{134}$

At bottom, SSD is a technical/engineering problem. If the technical elites are in agreement that emplacement not only represents the best HLW disposal option available, but also poses an inconsequential environmental risk, SSD would be considered

131 See Burial Place, supra note 4, at C12.

132 See id.

139 In contrast, terrestrial disposal is labor intensive, requiring elaborate monitoring and constant security for the life of the facility. See id. at Cl.

${ }^{134}$ Johnston, Marine Pollution Agreements: Successes and Problems, in INTERNATIONAL ENVIRONMENTAL DIPLOMACY, supra note 123, at 199, 204-05. 
"legal" under any of the sources of law analyzed above. ${ }^{135}$ Conversely, if there is either widespread disagreement or agreement that SSD is not a safe option, the law will follow this technical determination. In any event, the scientific evaluation will form the basis for the legal result. In practice, the important decision makers in the new SSD regime would be an international group of scientists entrusted by the member states with evaluating SSD at all stages of its development and impllementation.

\section{Depoliticization and Simplicity}

There are additional advantages to delegation of front-line authority to technical elites. The dialogue will focus appropriately on scientific analysis, with disputes largely resolvable empirically. Scientific controversies may be settled by resort to further experimentation. Given time and money, a consensus will usually emerge on issues such as the feasibility of a particular technology or the functioning of an ecosystem. In contrast, political disputes between nations depend more for their resolution on power relationships than on objective evaluations. Indeed, several recent attempts at regime creation have failed because a priori political/legal battles have resulted in intractable polarization-extremists either refused to compromise, ${ }^{136}$ or forced an unworkable compromise. ${ }^{137}$

135 If it will not harm the marine environment, SSD should be beyond the scope of the LDC and UNCLOS III, and certainly should be considered a reasonable use of the seas under customary international law. Any remaining challenges would be based upon emotional/philosophical/moral objections to the use of the oceans for the disposal of radioactive waste. See, e.g., E. BorGHESE, THE DRAMA Of THE OCEANS 213 (1975) (arguing that while the oceans may be the safest place on Earth to dispose of the wastes, even a small risk of harm makes disposal untenable); Comment, The Need for a Ban on All Radioactive Waste Disposal in the Ocean, 7 Nw. J. INT'L L. \& BUS. 803 (1986) (arguing for a ban on SSD on the basis of Professor Edith Brown-Weiss's "Planetary Trust" doctrine, which argues that the human species holds the natural resources of the planet in trust for all future generations).

${ }^{136}$ A proposed international agreement setting limits on exploitation of Antarctic resources was recently scuttled by two nations that took a maximalist environmental position, refusing to allow any commercial activity whatsoever in Antarctica. See Browne, France and Australia Kill Pact on Limited Antarctic Mining and Oil Drilling. N.Y. Times, Sept. 25, 1989, at Al0, col 1. Most nations shared the view of the U.S. State Department that "[i]t is better to have regulated exploitation than a legal vacuum in which no restraints of any kind are imposed on even the most environmentally hazardous exploitation." Id.

137 The International Seabed Authority created by UNCLOS III came into being as a concession to third world nations. See Malone, supra note 76, at 32 (stating that the ISA "would have been given the unprecedented power to redistribute wealth on an international scale"). 
Such factionalization tends to produce regimes that are weighted down with an all-encompassing agenda that therefore fail to accomplish even their primary mission. A salient example is the International Seabed Authority created under UNCLOS III, which attempts to carry out a controversial political agenda while regulating deep sea mineral recovery. ${ }^{138}$ Many industrialized nations have rejected UNCLOS III solely on the basis of the political implications of the seabed mining regime, placing the entire treaty in jeopardy.

Initial focus on or expansion into political issues would similarly serve as an anchor for a new SSD regime. A technical focus would tend to narrow the issues presented by SSD, increasing the chances of developing a reasoned and effective solution to the HLW problem. ${ }^{139}$

\section{CONCLUSION}

In the face of growing instability in the supply and price of fossil fuels, rapidly dwindling temporary storage capacity for highlevel nuclear waste, and the complete lack of viable disposal alternatives, the realistic question is not whether some form of SSD will take place, but rather under what international regulatory regime. Thus far, international consideration of the option has been legalistic and, from a global environmental perspective, unidimensional.

There has been a failure to recognize that nuclear waste disposal is more than merely a national problem. If one nation disposes of its waste improperly, the resulting catastrophe will eventually impact upon future generations, whether disposal takes place within

198 See Dubs, Minerals of the Deep Sea: Myth and Reality, in Pontecorvo, supra note 76, at 85, 111-17 (detailing the genesis of the ISA and controversial nature of third world claims to the seabed). In an excellent example of the polarization of the ISA debate, Malone notes that ISA and its theoretical underpinnings are

a guise under which the seabed's wealth was to be governed, regulated, and allocated under the false assumption that every nation has an undivided property interest in the deep seabed, and . . . is automatically entitled to its proportionate share of the fruits from those whose efforts produce wealth .... The [ISA] would have been given the unprecedented power to redistribute wealth on an international scale.

Malone, supra note 76, at 32 .

${ }^{139}$ See E. MILES, supra note 21, at 86 ("With respect to issues on an international regime agenda ... the narrower the scope of issues ... the higher the degree of certainty about efficient solutions because benefits and cost can be calculated fairly reliably ....”). 
national borders or in the global commons. More than twenty-five nations now generate significant quantities of nuclear waste; ${ }^{140}$ no nation has yet come close to finding a permanent solution to the disposal problem. In this respect, SSD is analogous to other pressing transboundary environmental problems, from global warming to ozone depletion. The solution to such issues will depend on unified action by the international community. Creation of a regime to address the questions presented by SSD may serve as a useful test case. To the extent it is possible to de-politicize the SSD regime, to make sound determinations about appropriate technology, and to bind all relevant state actors, one may be optimistic about the ability to address future transboundary issues.

As one report on global environmental prospects recently lamented, "[t]he Earth is one but the world is not." 141 Perhaps the creation of a viable subseabed emplacement regime would bring humankind one step closer to unifying the two.

140 See Moore, supra note 40, at 121.

141 WORLD COMM'N ON ENV'T \& DEV., OUR COMMON FUTURE 27 (1987). 